\title{
ACE Polymorphism and Modulation of some Specific Physical Variables in Boxers
}

\section{Mohamed Zakaria Baldam1 - Marwa Farouk Ghazy2 - Khaled Al-Sayed Sorour3}

\section{Background and Research Problem:}

Global advances in sport are not mere coincidence. Instead, it is the result of various efforts including sports training scientists who dedicate their time and effort to choose the most recent and most suitable training methods to make use of human abilities. Improving the performance level in boxing requires a scientific approach as physical fitness is a major factor in elite sports activities, especially boxing, and physical variables contribute greatly in improving the physical fitness levels and therefore enables the boxer to fulfill his tactical duties during real fight.

Salama, B. (1994) indicated that modern sports training rely basically on scientific knowledge and information. It gains its main material from humanitarian, medical and engineering applied sciences related to sport. In the past, sports talent played a major role in achieving elite levels but nowadays this is not possible without science-based sports training (30: 358-359).

Khedr, A. (1996) indicated that specific physical preparation in boxing is the key to elite levels as it identifies the levels of improvement for physical abilities in addition to functional positions of boxers. A well-fit boxer has the ability to work out all his body parts and of course he will be better than other boxers in technical performance and training without exhaustion. Without good physical preparation, a boxer cannot fight well, technically or tactically. An excellent factor for good physical preparation is training (18: 43).

Algebaly, O. (2000) indicated that the training process uses theories and sciences related to it like anatomy, physiology, kinesiology, psychology and sociology. This makes training a science that derives its characteristics from multiple sciences (5:6).

Genetics is the most recent science that penetrated into sport as modern countries started using genetic theories to reach elite sports levels.

Shaban, Y. (2007), quoting Bouchard \& Fox, indicated that genetics improved rapidly as genes play a major role in sport due to its responsibility about changes happening during physical preparation. Therefore, genes may be more important than training in interpreting differences among athletes (25: 56).

\footnotetext{
${ }^{1}$ Lecturer, Department of Combat Sports - Faculty of Physical Education - Tanta University

${ }^{2}$ Lecturer, Department of Sports Health Sciences - Faculty of Physical Education - Tanta University

${ }^{3}$ Lecturer, Department of Sports Training and Kinesiology - Faculty of Physical Education - Tanta University
} 
Heshmat, H. (1999) indicated that a gene represents the amount of information necessary to identify one peptide molecule. The number of human genes ranged from 50.000 to 100.000 . Mutations happen under the effects of X-ray or other substances. DNA preserves the genetic quality of an individual and each person has a completely different DNA. DNA identification is done by certain enzymes and this is known as the genetic print. The chance that two DNA prints are the same is 1: 4 billion. It is extremely rare unless in case of identical twins. DNA print is identified from blood samples, semen samples or other cells like mouth membranes. A DNA copy can be generated in laboratory using PCR or Polymerase Chain Reaction Technique (14: 2223).

Walfarth (2001) indicated that several studies proved the role of genes in identifying physical performance level. Studies on families indicated improvements in physical performance, especially $\mathrm{VO} 2 \max$ by nearly $50 \%$. Other studies on twins indicated improvements in physical performance due to training of certain body patterns that ranged from 50 to $60 \%$. This is due to the role of genes in improving physical performance and training levels (35: 207).

Hopkins (1998) indicated that if an athlete desires to reach elite levels in his/her specific sport, then he/she requires the suitable gene for that. One of the most important genes is ACE. It is called that way due to its links to Angiotensin Converting Enzyme which is active in muscular tissues as it regulates blood flow and therefore affects physical performance (15: 22).

Hopkins (1998) and Schneider et al (2001) recognized the important role of ACE in sports activities aiming to reach elite levels. Their studies on types of energy used by long, medium and short distance athletes, aerobic or anaerobic, indicated that the genetic type ACE D, prevalent among short distance athletes, was the catalyst for developing muscular strength. This type is the major cause of muscle hypertrophy as Ang. II cell growth agent exists. ACE has two main forms or types: the type I (stands for insertion) and the type $\mathrm{D}$ (stands for deletion). The only difference between the two types is the length of the dual base (15: 22) (31: 1072).

Montgomery et al (1998) indicated that ACE D gene is important in improving physical performance as it increases the mechanical efficiency of muscles. Other researchers did not agree with that. Fuentes et al (2002) indicated that the relationship between the two types of ACE ID gene and physical fitness and blood pressure was not proved (13: 221) (12: 250).

Hopkins (1998), Montgomery et al (1998), Abd El-Fattah, A. (2003), Fuentes et al (2002) and Tsiannos et al (2004) indicated the importance of ACE in sport as each individual owns a type of ACE gene. Polymorphism in this gene is clear as there is ACE II type (Insertion), ACE DD type (Deletion) and ACD ID. The type I is longer than the type D by 287 pairs (15: 3) (22: 5) (2: 67) (27) (34: 49).

Alsengary, S. (2006), Mabrouk, A. (2006) and Ali, M. (2006) indicated that when reading ACE location as (17Q23), then (17) stands for Chromosome (17) while (Q) stands for the long arm with three zones (1,2 and 3). The number (2) stands for the 
second zone while (3) stands for the third band as the second zone includes four bands. Angiotensin is a protein exerted in blood by the kidney. The gene responsible for exerting this enzyme is called Angiotensin Converting Enzyme Gene. This gene is located on the long arm of the chromosome (17). This gene appears on ends of the chromosome arms in two types: the insertion type or (I) and the deletion type or (D). When the type (I) appears, it is written as (II) and when the type (D) appears, it is written as (DD). If it appears on one arm as (I) and on the other as (D) it is written as (ID) and this means the chromosome holds the two types (10:22) (19:43) (8: 23-24).

Woods (2001), Myerson (1999) and Sonna et al (2001) indicated that the type ACE II is formed by 13000 pairs of nitrogen bases while the type ACE DD is formed by 13000 pairs of nitrogen bases minus 287. The type ACE ID is form by a number ranging between the two types (36: 230) (24: 1313) (31: 1355).

Abd El-Gaber, K. (2000), quoting Crodoplovw, indicated that integrated physical preparation of the boxer is the base for preparing the boxer technically and tactically and without it elite levels cannot be achieved. A boxer's movements should be quick with fast reactions during attack, defense or counterattack. A boxer should be strong and agile with great endurance. Quoting Novich \& Taylors, he also noted that boxers spend long years in strengthening their bodies and developing their agility and speed. They should also enjoy a great deal of endurance and flexibility (3:27).

Yaseen, A. (2002) noted that elite levels in boxing require science-based training as physical fitness is the key to elite levels in sport in general, and especially in boxing. Physical factors help improving physical fitness and therefore help boxers to fulfill their tactical duties (37: 5)

According to review of related literature and field experience of the researchers in boxing training, they noticed that some boxers are more advanced in physical fitness variables compared to their counterparts due to sports training while other boxers do not show the same level although the training variables are the nearly same.

The researchers think that this variability in boxers' responses to training may be due to differences in body and functional formation according to polymorphism. Some studies documented the importance of the two types of ACE gene (I and D) in improving physical performance while other studies did not find any relations between this polymorphism and physical performance. This paradox, in addition to the importance of selection according to genetic references, led the researchers to try to identify the relation between ACE polymorphism and the improvement of some physical variables in boxers. The researchers are trying to link sports training with biotechnology in boxing to achieve elite levels. This will provide coaches with scientific information concerning the effectiveness of training programs in the light of genetic polymorphism and this will help coaches to design suitable training programs for specific physical preparation.

This research is of particular importance as it tries to identify the relations between ACE polymorphism and training responses that help improving specific physical preparation of boxers. This will enable researchers and coaches to benefit from 
natural genetic aptitude of athletes for participating in specific sports suitable for them. This will help athletes to achieve elite levels of physical and functional performance through bio-techniques of selection. This will also help athletes to achieve better training results, save time and effort and concentrate on effective factors in boxing. Directing sports training according to athletes' genetic types will help greatly in achieving elite levels in specific sports. The researchers noticed a severe lack in studies dealing with the relation between genetic polymorphism and boxers' sports performance. This may be the first study on boxers. This led the researchers to try to identify the relations between ACE polymorphism and improvements of some physical variables in boxers.

Aim:

The current research aims to identify the relations between ACE polymorphism and improvements of some physical variables in boxers.

\section{Hypotheses:}

1. There are statistically significant differences between the pre- and postmeasurements of participants on physical variables in favor of the postmeasurements.

2. There is a statistically significant relation between ACE polymorphism and improvements of some physical variables under investigation. 


\section{Materials and Methods:}

Approach:

The researchers used the experimental approach (one-group design) with preand post-measurements.

Participants:

Research community included (13) young boxers (17-19 years) from ALSEKKA ALHADID Sports Club, Tanta Sorts Club and GHAZL Tanta Sports Club who are registered at the Egyptian Federation of Amateur Boxing. The researchers purposefully chose (8) boxers as a main sample while the other (5) were chosen for pilot sample. Participants were categorized according to their genetic type into two groups: group one (ACE DD) included (5) boxers - group two (ACE ID) included (3) boxers.

Participants were chosen due to their high technical and physical levels in addition to similarities in age and training period.

Table (1): Descriptive Data of Participants

\begin{tabular}{l|c|c|c|c|c|c}
\hline Groups & Variables & Measurements & Mean & SD & Median & Squewness \\
\hline \multirow{4}{*}{ Participants (n=8) } & Age & Year & 17.56 & 0.76 & 17.25 & 1.07 \\
\cline { 2 - 7 } & Height & $\mathrm{Cm}$ & 171.56 & 2.06 & 171.50 & 0.37 \\
\cline { 2 - 7 } & Weight & $\mathrm{Kg}$ & 69.50 & 2.33 & 69.00 & 0.18 \\
\cline { 2 - 7 } & Training period & Year & 3.49 & 0.36 & 3.55 & -0.09 \\
\hline \multirow{4}{*}{ ACE DD (n=5) } & Age & Year & 17.62 & 0.88 & 17.20 & 1.20 \\
\cline { 2 - 7 } & Height & $\mathrm{Cm}$ & 171.60 & 2.41 & 171.00 & 0.60 \\
\cline { 2 - 7 } & Weight & $\mathrm{Kg}$ & 69.20 & 2.39 & 69.00 & -0.21 \\
\cline { 2 - 7 } & Training period & Year & 3.54 & 0.38 & 3.60 & -0.07 \\
\hline \multirow{4}{*}{ ACE ID $(\mathrm{n}=3)$} & Age & Year & 17.47 & 0.67 & 17.30 & 1.06 \\
\cline { 2 - 7 } & Height & $\mathrm{Cm}$ & 171.50 & 1.80 & 172.00 & -1.15 \\
\cline { 2 - 7 } & Weight & $\mathrm{Kg}$ & 70.00 & 2.65 & 69.00 & 1.46 \\
\cline { 2 - 7 } & Training period & Year & 3.40 & 0.36 & 3.50 & -1.15 \\
\hline
\end{tabular}

Table (1) indicated that squewness values were between $( \pm 3)$. This indicates that data is free of radical distributions and all participants are homogenized in these variables.

Table (2): Difference Significance using Mann-Whitney non-parametric test for equivalence in growth factors

\begin{tabular}{|c|c|c|c|c|c|}
\hline Variable & Genetic type & Number & Mean of ranks & Sum of ranks & $\mathrm{Z}$ \\
\hline \multirow{2}{*}{ Age } & $\mathrm{DD}$ & 5 & 4.50 & 22.50 & \multirow{2}{*}{0.00} \\
\hline & ID & 3 & 4.50 & 13.50 & \\
\hline \multirow{2}{*}{ Height } & DD & 5 & 4.50 & 22.50 & \multirow{2}{*}{0.00} \\
\hline & ID & 3 & 4.50 & 13.50 & \\
\hline \multirow{2}{*}{ Weight } & DD & 5 & 21.00 & 4.20 & \multirow{2}{*}{0.45} \\
\hline & ID & 3 & 15.00 & 5.00 & \\
\hline \multirow{2}{*}{ Training period } & $\mathrm{DD}$ & 5 & 25.00 & 5.00 & \multirow{2}{*}{0.76} \\
\hline & ID & 3 & 11.00 & 3.67 & \\
\hline
\end{tabular}

Table two did not show any statistically significant differences between group one (ACE DD) and group two (ACE ID) on all variables under investigation as $\mathrm{Z}$ 
calculated values were less than its table value on $P \leq 0.05$. this indicates homogeneity of participants.

Data collection tools:

The researchers used several tools to collect data. This includes:

- Review of related literature to identify specific fitness components for boxers and their tests including:

* Speed strength: medicine ball throwing (lift / right)

* Speed endurance: punching the sand bag (lift / right) in (30) seconds

* Coordination: straight punches to a marks on the target in (1) minute

* Strength endurance: punching to a sand bag (lift / right) in (1) minute

- Training and physical measurement tools: gloves - boxing ring - dumbbells sand bags - ropes - medicine balls - stop watch

- Lab tests:

- Blood samples:

- EDETA anti-clotting was put in test tubes

- Blood samples were taken by $(10) \mathrm{cm}^{3}$ plastic syringes

- Only (5) $\mathrm{cm}^{3}$ were put test tubes with stirring slowly to extract plasma (with EDETA)

- Another (5) $\mathrm{cm} 3$ were put in empty test tubes to extract blood serum (without EDETA)

- All samples were preserved in an ice tank until transferred to lab

- All samples were centrifuged at the lab

- Plasma and serum were kept in deep freezers on $-20^{\circ}$

- PCR technique was applied

- A primer for each genetic type was used as an indicator for polymorphism

- For blood samples, all participants were instructed not to eat for (8) hours before testing and to remain cool without any physical efforts or medications. Blood samples were transferred quickly to labs

- Tools for blood tests: syringes - test tubes (with EDETA) - tube covers cotton - alcohol - plaster bandages - tube rack - EDETA anti-clotting - an ice tank for blood samples - a deep freezer $-20^{\circ}$ - automatic pipette for plasma - a centrifuge - a PCR primer

All lab tests were performed at the genetic lab of Genetics Center - Vacsera Cairo - Egypt.

Pilot study:

A pilot study was performed from 3-1-2015 to 5-1-2015 on a pilot sample $(n=5)$ from the same research community and outside the main sample. The study aimed to train assistant, to identify any difficulties that may face main application and to validate tools and tools. Results indicated that all tools are valid and assistants understand test procedures well. 
The recommended training program:

The program aimed to improve some specific physical qualities for boxers during preparation phase.

The program included several exercises for improving strength endurance, speed strength, speed endurance and coordination in addition to other physical, technical and tactical aspects required for boxers. Table (3) shows training loads and durations used in the program. The researchers considered the principles of improving physical qualities and all performances were similar to normal boxing performance.

Table (3): training durations and loads during the program

\begin{tabular}{l|l|c|c|c|c|c|c}
\hline Weeks & Percentage & Sunday & Tuesday & Thursday & Friday & Sum & Load \\
\hline 1 & According to level & 90 & 90 & 105 & 90 & 375 & Moderate \\
\hline 2 & $+15 \%$ of (1) & 105 & 105 & 120 & 100 & 430 & High \\
\hline 3 & $-30 \%$ of (2) & 75 & 75 & 75 & 75 & 300 & Moderate \\
\hline 4 & same as (2) & 105 & 105 & 120 & 100 & 430 & High \\
\hline 5 & $+15 \%$ of (4) & 120 & 120 & 135 & 120 & 495 & Max \\
\hline 6 & $-30 \%$ of (5) & 75 & 90 & 105 & 75 & 345 & Moderate \\
\hline 7 & Same as (5) & 120 & 120 & 135 & 120 & 495 & Max \\
\hline 8 & $-5 \%$ of (7) & 115 & 115 & 125 & 115 & 470 & Max \\
\hline 9 & $-30 \%$ of (7) & 75 & 75 & 105 & 75 & 330 & Moderate \\
\hline 10 & Same as (8) & 115 & 115 & 125 & 115 & 470 & Max \\
\hline 11 & Specific boxing high load & 90 & 105 & 120 & 90 & 405 & High \\
\hline 12 & Taper Total time (minutes) & 90 & 90 & 90 & 90 & 360 & Moderate \\
\hline \multicolumn{7}{c|}{ Total time (hours) } \\
\hline
\end{tabular}

Pre-measurements:

Blood samples were taken on 29-12-2014. Pre-measurements of physical tests were taken on 16-1-2015.

Main application:

The training program was applied from (12) weeks from 17-1-2015 to 9-4-2015 (4 units per week)

Post-measurements:

All post-measurements were taken on 10-4-2015

Statistical treatment:

The researchers used SPSS software to calculate: mean - SD - median squewness - Spearman's correlation coefficient - difference significance (Wilcoxon Man-Whitney) - percentage - relative variance. 


\section{Results:}

Table (4): Difference Significance between pre- and Post-measurements of participants on physical variables $(n=8)$

\begin{tabular}{|c|c|c|c|c|c|c|c|c|}
\hline $\begin{array}{l}\text { Physical } \\
\text { variable }\end{array}$ & Test & Measurement & $\begin{array}{c}\text { Pre- } \\
\text { measurement } \\
(\text { mean })\end{array}$ & $\begin{array}{c}\text { Post- } \\
\text { measurement } \\
(\text { mean })\end{array}$ & $\begin{array}{c}\text { Means } \\
\text { difference }\end{array}$ & $\begin{array}{l}\text { Positive } \\
\text { ranks }\end{array}$ & $\begin{array}{l}\text { Negative } \\
\text { ranks }\end{array}$ & Wilcoxon \\
\hline $\begin{array}{l}\text { Speed } \\
\text { strength } \\
\text { (right) }\end{array}$ & $\begin{array}{l}\text { Medicine } \\
\text { ball }\end{array}$ & M & 8.388 & 10.688 & 2.300 & 36 & 0 & 2.521 \\
\hline $\begin{array}{c}\text { Speed } \\
\text { strength (lift) }\end{array}$ & $\begin{array}{c}\text { Medicine } \\
\text { ball }\end{array}$ & M & 6.750 & 8.950 & 2.200 & 36 & 0 & 2.524 \\
\hline $\begin{array}{c}\text { Strength } \\
\text { endurance }\end{array}$ & $\begin{array}{c}\text { Punching } \\
(1 \mathrm{~min})\end{array}$ & Number & 84.375 & 139.00 & 54.625 & 36 & 0 & 2.524 \\
\hline Coordination & $\begin{array}{l}\text { Punching } \\
\text { to marks }\end{array}$ & Frequency & 13.850 & 8.950 & 4.900 & 36 & 0 & 2.521 \\
\hline
\end{tabular}

Table (4) showed statistically significant differences between the pre- and postmeasurements of participants on all physical variables in favor of post-measurements as Wilcoxon calculated values were higher than its table value on $\mathrm{P} \leq 0.05$.

Table (5): Relative variance between pre- and post-measurements for ACE DD group $(\mathbf{n}=\mathbf{5})$

\begin{tabular}{c|c|c|c|c|c|c}
\hline Physical variable & Test & Measurement & $\begin{array}{c}\text { Pre- measurement } \\
\text { (mean) }\end{array}$ & $\begin{array}{c}\text { Post-measurement } \\
\text { (mean) }\end{array}$ & $\begin{array}{c}\text { Means } \\
\text { difference }\end{array}$ & $\begin{array}{c}\text { Relative } \\
\text { variance }\end{array}$ \\
\hline $\begin{array}{c}\text { Speed strength } \\
\text { (right) }\end{array}$ & Medicine ball & $\mathrm{M}$ & 8.500 & 11.480 & 2.980 & 35.059 \\
\hline $\begin{array}{c}\text { Speed strength } \\
\text { (lift) }\end{array}$ & Medicine ball & $\mathrm{M}$ & 6.760 & 9.580 & 2.820 & 41.716 \\
\hline Speed endurance & $\begin{array}{c}\text { Punching (30 } \\
\text { sec) }\end{array}$ & Number & 45.00 & 95.600 & 50.600 & 112.444 \\
\hline $\begin{array}{c}\text { Strength } \\
\text { endurance }\end{array}$ & $\begin{array}{c}\text { Punching (1 } \\
\text { min) }\end{array}$ & Number & 83.00 & 121.600 & 38.600 & 46.506 \\
\hline Coordination & $\begin{array}{c}\text { Punching to } \\
\text { marks }\end{array}$ & Frequency & 13.840 & 9.060 & -4.780 & -34.538 \\
\hline
\end{tabular}

Table (5) showed that the highest relative variance was in speed strength $(112.44 \%)$ while the lowest value was in coordination $(-34.53 \%)$

Table (6): Relative variance between pre- and post-measurements for ACE ID $\operatorname{group}(\mathbf{n}=3)$

\begin{tabular}{c|c|c|c|c|c|c}
\hline Physical variable & Test & Measurement & $\begin{array}{c}\text { Pre- measurement } \\
\text { (mean) }\end{array}$ & $\begin{array}{c}\text { Post-measurement } \\
\text { (mean) }\end{array}$ & $\begin{array}{c}\text { Means } \\
\text { difference }\end{array}$ & $\begin{array}{c}\text { Relative } \\
\text { variance }\end{array}$ \\
\hline $\begin{array}{c}\text { Speed strength } \\
\text { (right) }\end{array}$ & Medicine ball & M & 8.200 & 9.367 & 1.167 \\
\hline $\begin{array}{c}\text { Speed strength } \\
\text { (lift) }\end{array}$ & Medicine ball & M & 6.733 & 7.900 & 1.167 \\
\hline $\begin{array}{c}\text { Speed endurance } \\
\text { Punching (30 } \\
\text { sec) }\end{array}$ & Number & 43.667 & 63.667 & 20.00 \\
\hline $\begin{array}{c}\text { Strength } \\
\text { endurance }\end{array}$ & $\begin{array}{c}\text { Punching (1 } \\
\text { min) }\end{array}$ & Number & 86.667 & 168.00 & 81.333 \\
\hline Coordination & $\begin{array}{c}\text { Punching to } \\
\text { marks }\end{array}$ & Frequency & 13.867 & 8.767 & -5.100 \\
\hline
\end{tabular}

Table (6) showed that the highest relative variance was in strength endurance (93.84\%) while the least value was in speed strength (right / lift) $(14.22 \%$ and $17.22 \%$ respectively). 
Table (7): Difference Significance between ACE DD and ACE ID groups on Physical variables under investigation

\begin{tabular}{|c|c|c|c|c|c|c|c|}
\hline physical variable & Test & ACE type & Number & Mean & Rank means & Rank sum & $\mathrm{Z}$ \\
\hline \multirow{2}{*}{ Speed strength (right) } & \multirow{2}{*}{ Medicine ball } & $\mathrm{DD}$ & 5 & 11.480 & 6.00 & 30.00 & \multirow{2}{*}{2.25} \\
\hline & & ID & 3 & 9.367 & 2.00 & 6.00 & \\
\hline \multirow{2}{*}{ Speed strength (lift) } & \multirow{2}{*}{ Medicine ball } & DD & 5 & 9.580 & 6.00 & 30.00 & \multirow{2}{*}{2.24} \\
\hline & & ID & 3 & 7.900 & 2.00 & 6.00 & \\
\hline \multirow{2}{*}{ Speed endurance } & \multirow{2}{*}{ Punching (30 sec) } & DD & 5 & 95.600 & 6.00 & 30.00 & \multirow{2}{*}{2.25} \\
\hline & & ID & 3 & 63.667 & 2.00 & 6.00 & \\
\hline \multirow{2}{*}{ Strength endurance } & \multirow{2}{*}{ Punching (1 min) } & DD & 5 & 121.600 & 3.00 & 15.00 & \multirow{2}{*}{2.24} \\
\hline & & ID & 3 & 168.00 & 7.00 & 21.00 & \\
\hline \multirow{2}{*}{ Coordination } & \multirow{2}{*}{ Punching to marks } & $\mathrm{DD}$ & 5 & 9.060 & 5.10 & 25.50 & \multirow{2}{*}{0.90} \\
\hline & & ID & 3 & 8.767 & 3.50 & 10.50 & \\
\hline
\end{tabular}

Table (7) shows statistically significant differences between ACE DD and ACE ID groups on speed strength and speed endurance in favor of ACE DD group while the difference were in favor of ACE ID group on strength endurance. Coordination did not show any statistically significant differences.

Table (8): Differences between relative variance values of pre- and postmeasurements for ACE DD and ACE ID groups on all physical variables

\begin{tabular}{|c|c|c|c|c|c|c|c|}
\hline \multirow{2}{*}{$\begin{array}{l}\text { Physical } \\
\text { variable }\end{array}$} & \multirow[b]{2}{*}{ Test } & \multirow[b]{2}{*}{ Measurement } & \multicolumn{2}{|c|}{ ACE DD } & \multicolumn{2}{|c|}{ ACE ID } & \multirow[b]{2}{*}{ Difference } \\
\hline & & & $\begin{array}{c}\text { Means } \\
\text { difference }\end{array}$ & $\begin{array}{l}\text { Relative } \\
\text { variance }\end{array}$ & $\begin{array}{c}\text { Means } \\
\text { difference }\end{array}$ & $\begin{array}{l}\text { Relative } \\
\text { variance }\end{array}$ & \\
\hline $\begin{array}{c}\text { Speed } \\
\text { strength } \\
\text { (right) }\end{array}$ & $\begin{array}{c}\text { Medicine } \\
\text { ball }\end{array}$ & M & 2.980 & 35.059 & 1.167 & 14.228 & 20.831 \\
\hline $\begin{array}{c}\text { Speed } \\
\text { strength (lift) }\end{array}$ & $\begin{array}{l}\text { Medicine } \\
\text { ball }\end{array}$ & M & 2.820 & 41.716 & 1.167 & 17.327 & 24.389 \\
\hline $\begin{array}{c}\text { Speed } \\
\text { endurance }\end{array}$ & $\begin{array}{c}\text { Punching } \\
(30 \mathrm{sec})\end{array}$ & Number & 50.600 & 112.444 & 20.00 & 45.801 & 66.643 \\
\hline $\begin{array}{l}\text { Strength } \\
\text { endurance }\end{array}$ & $\begin{array}{l}\text { Punching } \\
\text { (1 min) }\end{array}$ & Number & 38.600 & 46.506 & 81.333 & 93.846 & 47.34 \\
\hline Coordination & $\begin{array}{l}\text { Punching } \\
\text { to marks }\end{array}$ & Frequency & -4.780 & -34.538 & -5.100 & -36.779 & 2.241 \\
\hline
\end{tabular}

Table (8) indicated that the highest relative variance was in speed endurance (66.64\%) in favor of ACE DD group, followed by strength endurance (47.34\%) in favor of ACE ID group, then speed strength (right/lift) (20.8\% and $24.38 \%$ respectively) in favor of ACE DD group while the least value was in coordination $(2.24 \%)$ in favor of ACE DD group.

\section{Discussion:}

Table (4) showed statistically significant differences between the pre- and postmeasurements of participants on all physical variables in favor of post-measurements as Wilcoxon calculated values were higher than its table value on $P \leq 0.05$. this indicates improvements on these tests. The researchers think that this is due to regular training applied to participants to improve specific fitness components including speed strength, strength endurance, speed endurance and coordination. This is consistent with Abd El- 
Baseer, A. (1999), Mahmoud, S. (2000) and Abe El-Khalek, E. (2003) who indicated that regular training improves physical fitness (7: 72) (21: 17) (23: 106).

This proves the first hypothesis stating that "There are statistically significant differences between the pre- and post-measurements of participants on physical variables in favor of the post-measurements".

Table (5) showed that the highest relative variance was in speed strength (112.44\%) followed by (46.5\%) for speed strength (lift) and (41.7\%) for speed strength (right) while the lowest value was in coordination (-34.53\%) for ACE DD group. Table (6) showed that the highest relative variance was in strength endurance $(93.84 \%)$ followed by $(45.8 \%)$ for speed endurance and $(36.7 \%)$ for coordination while the least value was in speed strength (right / lift) (14.22\% and 17.22\% respectively) for ACE ID group. These results indicated clear variance in some physical fitness components between the two groups. The researchers think that this is due to ACE polymorphism. This is consistent with Al-Hawy, Y. (2004) who indicated that genetics play a major role in the characteristics, improvement and development of sports talents (6:110).

Taha, M. (2002) indicated that genetics affect structural and morphological characteristics of athletes including his/her musculoskeletal system, neurological system and glands in addition to other vital organs. He also thinks that differences in genetic aptitudes distinguish one athlete from another and affect his/her performance through training and competitions (33: 31$)$.

Table (7) shows statistically significant differences between ACE DD and ACE ID groups on speed strength and speed endurance in favor of ACE DD group while the difference were in favor of ACE ID group on strength endurance. Coordination did not show any statistically significant differences. This means that ACE polymorphism affected speed strength, speed endurance and strength endurance but did not affect coordination. This is consistent with Hopkins (1998) who indicated that ACE ID type provides higher response to endurance training (15: 3).

This is also consistent with Nazarov et al (2001) who indicated that ACE DD type is common among strength athletes characterized by fast twitch (white) muscular fibers, higher muscular volume and higher glucose- based energy production (27: 797).

Table (8) indicated that the highest relative variance was in speed endurance (66.64\%) in favor of ACE DD group, followed by strength endurance (47.34\%) in favor of ACE ID group, then speed strength (right/lift) (20.8\% and $24.38 \%$ respectively) in favor of ACE DD group while the least value was in coordination $(2.24 \%)$ in favor of ACE DD group.

Al-khodary, H. (2004) indicated that genetic polymorphism affects physiological fitness and health in humans as the type of genes has a significant effect on the rate and volume of responses to continuous stimuli like physical exercises (9: 54-55). 
Abd Al-Rahman, N. and Fekry, S. (2004) indicated that variance in response to the same training among athletes is due to several factors and the most important of them are genetic factors (4: 196).

The researchers think that genetic polymorphism is responsible for improving some, and not all, variables in each group. ACE DD group witnessed improvements in speed endurance and speed strength while ACE ID group witnessed improvement in strength endurance and coordination remained indifferent between the two groups.

This is consistent with the results of Ali, M. (2006) as improvements were clear in anaerobic capacity, speed and strength for ACE DD type athletes. Al-Ziky, H. (2006) indicated that speed strength and strength improved for ACE DD type athletes while cardio-vascular endurance improved in ACE ID type athletes. Yames (2000) indicated that ACE DD type is dominant in improving muscular strength as athletes with this genetic type surpassed their ACE II type counterparts. Tsianos et al (2004) indicated that ACE DD type is related to improved records on short distance anaerobic race while ACE ID type is related to improved records on long distance aerobic races. Yolakoglu et al (2005) indicated that athletes with ACE DD type improved their strength to higher levels compared to athletes with ACE II/ID types (8) (11) (17) (38).

This proves the second hypothesis stating that"There is a statistically significant relation between ACE polymorphism and improvements of some physical variables under investigation".

\section{Conclusions:}

According to this research aim, materials, methods and results, the researchers concluded the following:

1. Boxers of ACE DD group are characterized by speed endurance and speed strength compared with ACE ID group. Differences in relative variance were $66.64 \%$ and $20.8 \%$ and $24.38 \%$ on speed endurance and speed strength (right/lift) respectively in favor of ACE DD group.

2. Boxers of ACE ID group are characterized by strength endurance compared to ACE DD group as difference in relative variance was $47.34 \%$ in favor of ACE ID group.

3. There were no statistically significant differences between ACE DD and ACE ID groups on coordination as difference in relative variance was only $2.24 \%$ in favor of ACE DD group.

\section{Recommendations:}

According to this research results and conclusions, the researchers recommend the following:

- Using bio-technology in athletic selection .

- Performing a study to categorize junior boxers according to ACE polymorphism.

- Performing a study to identify the relation between ACE polymorphism and other specific fitness components for boxers . 
- Performing a study to identify the relation between ACE polymorphism and physiological variables for boxers.

- Increasing training dosage for boxers who lack ACE DD type to increase their anaerobic abilities .

- Increasing training dosage for boxers who lack ACE ID type to increase their aerobic abilities.

- Establishing a center for genetic research with specialized labs to use it in selection and sports training processes.

\section{References:}

1- Abd El-Fattah, Abu Al-Ela Ahmed (1997): Sports Training and Physiology. Dar Al-Fikr AlAraby - Cairo - Egypt (in Arabic)

2- Abd El-Fattah, Abu Al-Ela Ahmed (2003): Physiology of Training and Sport. Dar Al-Fikr Al-Araby - Cairo - Egypt (in Arabic)

3- Abd El-Hafez, Kamal Abd El-Gaber (2000): Effects of isotonic muscular work on improving muscular strength for some punches in boxers. PhD thesis, Faculty of Physical Education - Asiut University - Egypt (in Arabic)

4- Abd El-Rahman, Nabila A. \& Fekry, Salwa E. (2004): Sports Training System: Philosophy education - physiology - biomechanics - administration. Dar Al-Fikr Al-Araby Cairo - Egypt (in Arabic)

5- Algebaly, Oais Ali (2000): Sports Training: Theory and Practice. GMS press - Cairo Egypt (in Arabic)

6- Al-Hawy, Yahia Ismail (2004): Sports Talent and Motor Creativity: The Golden Gate to International Sport. The Arab Center Press - Cairo - Egypt (in Arabic)

7- Ali, Adel abd El-Baseer (1999): Sports Training: Integrating theory and practice. Markaz AlKetab Press - Cairo - Egypt (in Arabic)

8- Ali, Mohamed Mohamed (2006): Relationship between genetic type and biological response in selecting junior endurance athletes. PhD thesis, Faculty of Physical Education Al-Minia University - Egypt (in Arabic)

9- Al-Khodary, Huda Mohamed (2004): Modern Techniques in selecting talented junior swimmers. The Egyptian Library - Alexandria - Egypt (in Arabic)

10-Alsengery, Sherif Mohamed (2006): Genetic indicators of lift ventricle volume and its relation to digital records of junior swimmers. PhD thesis, Faculty of Physical Education - Benha University - Egypt (in Arabic)

11-Al-Ziky, Hazem Reda (2007): Using genetic indicators to guide training and its effects on the physical and functional performance of junior soccer players. PhD thesis, Faculty of Physical Education - Mansoura University - Egypt (in Arabic)

12-Fuentes, R., Perole, M., Tuomilehto, J. (2002): "ACE Gene and physical activity, Blood Pressure and hypertension" 2002, Apop ulation study in Finland, J. APPL. physiol vol. 22 page : 2508

13-Hafez, Samy, Moheb (2006): Introduction to modern boxing, $2^{\text {nd }}$ ED. Shagart Al-Dor Press Mansoura - Egypt (in Arabic)

14-Heshmat, Husain Ahmed (1999): Biological and bio-chemical techniques and its application in sport. Universities Press - Caior - Egypt (in Arabic)

15-Hopkins, W. (1998): " Performance gene discovered sport Science", 1998, 2, (4)

16-Ismail, Kamal A. \& Hasanain, Mohamed S. (1997): Principles of sports training for improving physical fitness in physical education lesson. Dar Al-Fikr Al-Araby Cairo - Egypt (in Arabic)

17-James Meek (2002): Gene governs muscle power, 2002, Thursday February 10, the guardian. 
18-Khedr, Abd El-Fattah Fathy (1996): Textbook in Boxing. Munshaat Al-Maaref - Alexandria - Egypt (in Arabic)

19-Mabrouk, Abd El-Kafy Ahmed (2006): ACE polymorphism and its relation to the performance level of Libyan Handball Players. PhD thesis, Faculty of Physical Education for men - Alexandria University - Egypt (in Arabic)

20-Mahmoud, Husam Refky (1993): Boxing: Theory and Practice. Egyptian Renaissance library - Cairo - Egypt 9in Arabic)

21-Mahmoud, Musaad Ali (2000): Introduction to sports training. Mansoura University Press Mansoura - Egypt (in Arabic)

22-Montgomry, H., Clarkson, P., Humphries, S. (1998): "Human gene for Physical performance", 1998, Nature vol. 393, P. 221 - 222.

23-Musafa, Isam El-Din Abd El-Khalek (2003): Sports Training: Theory and Practice $3^{\text {rd }}$ ED Dar Al-Maaref - Alexandria - Egypt (in Arabic)

24-Myerson S. et. al., (1999): "Human Angiotensin converting Enzyme Gene and Endurance Performance ", 1999, J. Appl. Physiology, Vol. 87, Issue 4, P.P. 1313-1316.

25-Nabeeh, Yaser Shaban (2007): Genetic polymorphism and its role in developing body components as a means for selecting boxers. Master thesis, Faculty of Physical Education - Zagazig University - Egypt (in Arabic)

26-Nasr, Mustafa Mohamed (2007): Effects of training program for complex physical characteristics on some physiological variables and effective technical performance of young boxers. PhD thesis, Faculty of Physical Education - Mansoura University Egypt (in Arabic)

27-Nazarov. Bigor, David R. woods, Vasiliy I. Kazakov (2001): "The ACE I/D Polymarphism in Russian Athletes ", 2001 , European Journal , Human Genetics, p.p. 797-801

28-Othman, I., Ghonaim, M., Ahmed, D. and Shalan, A. (2001): Boxing Training and Instruction $2^{\text {nd }}$ ED. Dar Al-Saada Press - Cairo - Egypt (in Arabic)

29-Peter Janssen ,MD (2001): Lactat Threshold training, Human Kinetic, United States of America, 2001

30-Salama, Bahaa El-Din Ibrahim (1994): Sports Physiology $2^{\text {nd }}$ ED. Dar Al-Fikr Al-Araby Cairo - Egypt (in Arabic)

31-Schneider, O., Nazarov, I., Tomilin, N. (2001): "ACE D allele - the role of genes in athletic performance", 2001, 6 An. Con. Eur.Col.Sport Sc., P.1072.

32-Sonna L. A. et. al. (1999): "Angiotensin converting Enzyme Genotype and physical Performance During U.S. Army Basic Training", 1999, J. Appl. Physiology , Vol. 91 , Issue 3 , P.P. 1355-1363.

33-Taha, Mohamed Lotfy (2002): Psychological Bases of Sports Selection. General association for Governmental Press - Cairo - Egypt (in Arabic)

34-Tsianos. G. et. al., (2004): "The ACE gene insertion / deletion polymorphism and elite endurance swimming", 2004, Euro j Appl physiol. 92: 360 - 362.

35-Walfarth, B. (2001): "Genetic polymorphism and perfprmance related phenotypes" , 2001 , An Overview 6 An. Con. , Eur. Col. Sport Sc.,P. 207

36-Woods D. et. al., (2001): "Elite Swimmers and The D Allele Of The ACE I/D Polymorphism ", 2001, Human Genet. , 108(3) , P.P. 230-232.

37-Yaeen, Yaseen Ahmed (2002): A training program for specific fitness components for boxers according to expected objectives. PhD thesis, Faculty of Physical Education for Men - Helwan University - Egypt (in Arabic)

38-Yolakoglu. M, et. al., (2005): "ACE Genotype May have an effect on single versus multiple set preferences in strength training", 2005, Euro, Appl. Physiol. 